Wang, C. Y., Phase transitions in rocks under shock compression, Earth Planet. Sci. Lett. 2, 107-113, 1967.

Wang, C. Y., Constitution of the lower mantle as evidence from shock wave data for some rocks, J. Geophys. Res., 73, 6459-6476, 1968a.

Wang, C. Y., Equation of state of periclase and Birch's relationship between velocity and density, Nature, 218, 74, $1968 b$.
Weaver, J. S., Taro Takahashi, and W. A. Bassett, Calculation of the $P$-V relation for the B1 phase of $\mathrm{NaCl}$ up to 300 kilobars at $25^{\circ} \mathrm{C}$, in Proceedings of Symposium on Accurate Characteri. zation of High Pressure Environments, edited by E. Lloyd, National Bureau of Standards, Gaithersburg, Md., 1968.

Weir, C. E., G. J. Piermarini, and S. Block, Instrumentation for single crystal X-ray diffraction at high pressures, Rev. Sci. Instrum. 40, 1133-1136, 1969.

\title{
Melting Relations
}

\section{Peter J. Wyllie}

The process of magma generation with subsequent uprise and intrusion or extrusion of magma is one of the fundamental processes in the evolution of the earth. Rheological and other physical properties change markedly wherever and whenever partial melting occurs. The melting relations of minerals and rocks can now be measured in the laboratory to pressures corresponding to depths of more than $250 \mathrm{~km}$. The measurements provide limits for temperatures within the earth and a basis for extrapolation to greater depths. This report outlines experimental results for the melting of elements, minerals, and rocks under various conditions, in a dry state or in the presence of water and other volatile components. There is overlap with reports on experimental petrology in another section, but it is reduced to a minimum by limiting this review to melting curves and properties, without attention to the more detailed aspects of petrogenesis.

Luedemann and Kennedy [1968] measured the melting curves of lithium, sodium, potassium, and rubidium to $80-\mathrm{kb}$ pressure. At about $60 \mathrm{~kb}$ they found rather sharp changes in the slope of the melting curves for lithium, potassium, and rubidium that could represent maximums in fusion curves analogous to the maximum previously discovered for cesium. The relationship between the temperature of melting for a given pressure and the compression measured at room temperature was discussed by Luedemann and Kennedy and Kennedy and Vaidya [1970]. The linear relationship for metals breaks down at pressures where maximums occur on the fusion curves. Gilbert [1969] found that the linear relationship does not appear to hold for silicate minerals. Kennedy and Vaidya proposed a re-evaluation of the various equations used to describe the effects of pressure on fusion temperatures. Extrapolation of melting curves for silicates or metals for estimation of melting temperatures in the deep mantle and core remains uncertain.

Between 1958 and 1964 the availability of the piston-cylinder apparatus had yielded melting curves to mantle pressures for a number of silicate minerals: albite, diopside, fayalite, forsterite, jadeite, and pyrope. Additional fusion curves for individual minerals and for

Peter J. Wyllie is with the Department of Geophysical Sciences, University of Chicago, Chicago, Illinois 60637. mineral assemblages have since been reported. The fusion curve for fayalite was measured to $40 \mathrm{~kb}$ by $\mathrm{Hsu}$ [1967] and extended to higher pressures above the olivine-spinel transition by A kimoto and Komada [1967]. Gilbert [1969] presented a melting curve for acmite to $45 \mathrm{~kb}$. Using a differential thermal analysis technique with tungsten/rhenium thermocouples, Williams and Kennedy [1969] redetermined the melting curve of diopside, to $50-\mathrm{kb}$ pressure. They claimed considerable improvement over existing methods employing quench techniques and platinum-rhodium thermocouples. Lindsley [1966, 1967] described melting relationships for sanidine and parts of the system $\mathrm{KAlSiO}_{4}-\mathrm{SiO}_{2}$ to 40 kb. Bell and Roseboom [1969] presented data for albite and jadeite and derived all theoretically possible types of $P-T \cdot X$ diagrams for melting at high pressures with four solid phases of different compositions (jadeite, albite, quartz, and nepheline) in a binary system ( $\mathrm{NaAl}$ $\mathrm{SiO}_{4}-\mathrm{SiO}_{2}$ ). Luth [1969] presented the eutectic melting relationships for $\mathrm{NaAlSi}{ }_{3} \mathrm{O}_{8}-\mathrm{SiO}_{2}$ and $\mathrm{KAlSi}{ }_{3} \mathrm{O}_{8}-\mathrm{SiO}_{2}$ to $20 \mathrm{~kb}$ and found that the composition of the eutectic liquid was enriched in the feldspar component with increasing pressure. Bell and Davis [1969] described melting relationships in the system jadeite-diopside at 30 and $40 \mathrm{~kb}$.

More complex silicate systems have been studied. Kushiro [1968] studied liquid compositions in a series of systems $\mathrm{Mg}_{2} \mathrm{SiO}_{4}-\mathrm{SiO}_{2}-X$, where $X$ represents $\mathrm{CaMgSiO}_{4}, \mathrm{CaAl}_{2} \mathrm{O}_{4}, \mathrm{NaAlSiO}_{4}$, and $\mathrm{MgAl}_{2} \mathrm{O}_{4}$. His results in the pressure range 7 to $40 \mathrm{~kb}$ were applied to the problem of the compositions of magmas formed at various depths by partial fusion of mantle peridotite. He described also the phase relationships in the system $\mathrm{Mg}_{2} \mathrm{SiO}_{4}-\mathrm{CaMgSi} \mathrm{O}_{6}-\mathrm{SiO}_{2}$ at $20 \mathrm{~kb}$ [Kushiro, 1969]. O'Hara and Yoder [1967] reviewed the formation and fractionation of basic magmas at high pressures by using results at $30 \mathrm{~kb}$ on the join $\mathrm{CaMgSi}_{2} \mathrm{O}_{6}-\mathrm{Mg}_{3} \mathrm{Al}_{2} \mathrm{Si}_{3} \mathrm{O}_{12}$ and adjacent parts of the plane $\mathrm{CaSiO}_{3}-\mathrm{MgSiO}_{3}-\mathrm{Al}_{2} \mathrm{O}_{3}$ and similar compositions obtained by mixing natural minerals separated from a garnet-peridotite nodule from a kimberlite. The effect of pressure on the system $\mathrm{MgO}-\mathrm{SiO}_{2}-\mathrm{TiO}_{2}$ was determined by MacGregor [1969]. Liquids became progressively richer in $\mathrm{TiO}_{2}$ as pressure increased to $40 \mathrm{~kb}$. The melting relationships to $20 \mathrm{~kb}$ for the composition $\left(\mathrm{An}_{70} \mathrm{Ab}_{30}\right)_{3} \mathrm{Fo}_{1}$ were determined by Emslie and Lindsley [1969], as a guide to anorthosite genesis.

Presnall [1969] presented a detailed geometrical analysis of partial fusion by using simple systems as examples. 
Melting relationships between solidus and liquidus of complex compositions, natural rocks, have been determined to mantle pressures. The results have been applied to problems of basaltic magma generation and the effects of partial fusion on the upper mantle properties. In companion papers, Cohen et al., [1967] and Ito and Kennedy [1967] presented melting relationships for tholeiitic basalt and a peridotite to $40 \mathrm{~kb}$. Ito and Kennedy [1968] extended the compositional range by using several other basaltic or olivine-rich rocks. Emslie and Lindsley [1969] determined the melting interval to $20 \mathrm{~kb}$ of the chilled margin of an anorthosite body.

The melting relationships of sulfides have also been extended to mantle pressures. Sharp [1969] reported melting curves for sphalerite, galena, and phyrrotite to $65 \mathrm{~kb}$. The melting relationships at $30 \mathrm{~kb}$ in the Fe-rich portion of the system Fe-FeS were described by Brett and Bell [1969]. They concluded that even a small percentage of sulfur in the earth's core could produce a significant effect on the melting relationships of the core. Sharp noted that, if silicate magmas form at depths below $250 \mathrm{~km}$, sulfide magma should also form; its downward intrusion could possibly help to explain the origin of deep earthquakes.

Boettcher and Wyllie [1967] reported use of the piston-cylinder apparatus to extend low-pressure hydrothermal melting curves to mantle pressures. Merrill et al. [1970] determined the solidus curves with excess water to $20 \mathrm{~kb}$ for the systems $\mathrm{NaAlSi}_{3} \mathrm{O}_{8}-\mathrm{KAlSi}_{3} \mathrm{O}_{8}-\mathrm{H}_{2} \mathrm{O}$ and $\mathrm{NaAlSi}_{3} \mathrm{O}_{8}-\mathrm{KAlSi}_{3} \mathrm{O}_{8}-\mathrm{SiO}_{2}-\mathrm{H}_{2} \mathrm{O}$, and they reviewed available melting results in feldspar-quartz- $\mathrm{H}_{2} \mathrm{O}$ systems, presenting in figures and tabular form results for all of the solidus curves. Morse [1970] studied alkali feldspar melting relations with excess $\mathrm{H}_{2} \mathrm{O}$ at $5 \mathrm{~kb}$. The low-pressure crustal pattern changes at mantle pressures, where albite and anorthite break down to yield dense minerals such as jadeite, kyanite, and zoisite; here, the familiar negative slope $(d P / d T)$ of solidus curves changes to positive, and the melting curves with excess water then trend in the same direction as the dry melting curves. Boettcher and Wyllie [1969a] extended the melting curves for minerals and mineral assemblages in the system $\mathrm{NaAlSiO}_{4}-\mathrm{SiO}_{2}-\mathrm{H}_{2} \mathrm{O}$ from 10 to $35 \mathrm{~kb}$; they traced in detail the series of univariant curves and invariant points involved in the transition from the low-pressure albite-quartz-nepheline-analcite assemblages to the high-pressure assemblages including jadeite. Lambert et al. [1969] reported curves for sanidine- $\mathrm{H}_{2} \mathrm{O}$ and sanidine-quartz- $\mathrm{H}_{2} \mathrm{O}$ to $18.5 \mathrm{~kb}$. Melting curves for anorthite- $\mathrm{H}_{2} \mathrm{O}$ and anorthite-quartz- $\mathrm{H}_{2} \mathrm{O}$ were reported to $10 \mathrm{~kb}$ by Stewart [1967] and to higher pressures by Boettcher [1970]. Boettcher enlarged his study to include many other melting and subsolidus reactions in the system $\mathrm{CaO}-\mathrm{Al}_{2} \mathrm{O}_{3}-\mathrm{SiO}_{2}-\mathrm{H}_{2} \mathrm{O}$, and he traced the transition from low-pressure to high-pressure mineralogy.

The effect of water on the melting of enstatite reported by Kushiro et al. [1968] indicated conditions for melting in the system $\mathrm{MgO}-\mathrm{SiO}_{2}-\mathrm{H}_{2} \mathrm{O}$ at mantle pressures. Kushiro [1969] compared results at $20 \mathrm{~kb}$ for the system forsterite-diopside-silica, both dry and with excess water, and he presented results on liquid compositions for a number of systems with excess water: forsterite-nepheline-silica- $\mathrm{H}_{2} \mathrm{O}$, forsterite- $\mathrm{CaAl}_{2} \mathrm{SiO}_{6}$. silica- $\mathrm{H}_{2} \mathrm{O}$, forsterite-nepheline- $\mathrm{CaAl}_{2} \mathrm{SiO}_{6}-\mathrm{H}_{2} \mathrm{O}[\mathrm{Kush}$ ro, 1970a].

Addition of water as a component introduces hydrous minerals. Lambert et al. [1969] deduced the melting relationships of muscovite, alone or with quartz and sanidine, dry or with excess water, to $20-\mathrm{kb}$ pressure. Yoder and Kushiro [1969] presented melting curves for phlogopite, with excess water up to $37 \mathrm{~kb}$, and dry up to $10 \mathrm{~kb}$. Modreski and Boettcher [1970] described the melting relationships of phlogopite and enstatite, with forsterite, dry and with excess water; Kushiro [ $1970 b]$ reported similar preliminary results. The melting relationships of amphiboles have been determined in connection with whole-rock studies.

Yoder [1969] concluded that water is the major factor in determining the composition and behavior of andesites. Andesites and associated batholithic rocks of island arcs and active continental martins may have their origin in mantle rocks or in crustal rocks at crustal or mantle pressures. Phase relationships with excess water to $3 \mathrm{~kb}$ have been determined through the melting interval for a number of plutonic igneous rock series [Piwinskii and Wyllie, 1968, 1970; Piwinskii, 1968; Gibbon and Wyllie, 1969; McDowell and Wyllie, 1967\}. Boettcher and Wyllie [1968] extended the granite-water solidus curve to $35 \mathrm{~kb}$. Similar curves for the major crustal rocks with excess water were compiled and reviewed by Merrill et al. [1970] and compared with feldspar-quartz- $\mathrm{H}_{2} \mathrm{O}$ curves. They show similar changes in slope at about $17 \mathrm{~kb}$, where plagioclase breaks down. Phase relationships through the melting interval of gabbro composition with excess water to 25 or $35 \mathrm{~kb}$ have been reported by Lambert and Wyllie [1968, $1970 a, 1970 b$ ] and Hill and Boettcher [1970]. Millhollen and Wyllie [1970] presented similar results for an alkalic ultrabasic rock. Lambert and Wyllie [1970a] worked with tonalite- $\mathrm{H}_{2} \mathrm{O}$ to $25 \mathrm{~kb}$ (similar to andesite in composition). Kushiro [1970b] described amphibole stability with respect to a previously determined solidus for peridotite- $\mathrm{H}_{2} \mathrm{O}$. The effect of oxygen fugacity on melting of gabbroic compositions with excess water at 5 $\mathrm{kb}$ was studied by Tuthill [1969]. Melting relationships in peridotites and gabbros with excess water were reviewed by Wyllie [1970].

The melting relationships in systems with mixed volatiles have been extended to $35 \mathrm{~kb}$ : $\mathrm{CaO}-\mathrm{CO}_{2}-\mathrm{H}_{2} \mathrm{O}$ [Wyllie and Boettcher, 1969] and $\mathrm{CaO}-\mathrm{SiO}_{2}-\mathrm{CO}_{2}-\mathrm{H}_{2} \mathrm{O}$ [Boettcher and Wyllie, 1969b]. The solidus curve for $\mathrm{CaO}-\mathrm{SiO}_{2}-\mathrm{CO}_{2}-\mathrm{H}_{2} \mathrm{O}$ terminates at a second critical end point at about $32 \mathrm{~kb}$. Yoder [1970] investigated the effect of $\mathrm{CO}_{2}$ on melting in the system phlogopite- $\mathrm{H}_{2} \mathrm{O}$ at $10 \mathrm{~kb}$. The melting intervals of various rocks have been studied in the presence of $\mathrm{H}_{2} \mathrm{O}-\mathrm{CO}_{2}$ mixtures. Gabbro- $\mathrm{H}_{2} \mathrm{O}-\mathrm{CO}_{2}$ with oxygen fugacity buffered was studied by Holloway and Burnham [1969] to $8 \mathrm{~kb}$. Eggler [1970] and Millhollen [1970] studied andesite and nepheline syenite, respectively, at pressures below $10 \mathrm{~kb}$. Hill and Boettcher [1970] compared melting 
results for gabbro to $35 \mathrm{~kb}$ with the results for water or for $\mathrm{H}_{2} \mathrm{O}-\mathrm{CO}_{2}$ mixtures.

The effect of salt solutions on the melting relations of albite have been reported by Koster van Groos and Wyllie [1968a, $\left.\mathrm{Na}_{2} \mathrm{CO}_{3} ; 1968 b, \mathrm{NaF} ; 1969, \mathrm{NaCl}\right]$.

Most melting and crystallization processes in the earth's mantle and crust occur in water-deficient regions. (See Burnham [1967] for discussion.) Yoder and Kushiro [1969] published results at 10 -kb pressure for melting in the system phlogopite- $\mathrm{H}_{2} \mathrm{O}$ both with excess water and with insufficient water present to saturate the liquid.

Experimental results for rocks under water-deficient conditions at crustal pressures have been presented by Whitney and Luth [1970] and Robertson [1970]. Eggler [1970] achieved similar conditions by using' $\mathrm{CO}_{2}-\mathrm{H}_{2} \mathrm{O}$ mixtures.

The properties of partially melted materials are most significant for interpretation of geophysical measurements. Walsh [1968, 1969] used an analytical approach to calculate the attenuation in partly melted material. Birch [1969] also considered this problem. Spetzler and Anderson [1968] measured experimentally the longitudinal and shear velocities and attenuations in the system ice-salt with the onset of melting. The results support proposals that the low-velocity zone of the upper mantle is partially melted [Lambert and Wyllie, 1968; Anderson and Sammis, 1969; Archambeau et al., 1969; Anderson, 1970]. Lambert and Wyllie [1968] and Anderson and Sammis [1969] suggested that incipient melting can occur at moderate temperatures in this zone if traces of water are present.

The viscosity of basaltic magma has been measured in a Hawaiian lava lake [Shaw et al., 1968], and Shaw [1969] has discussed the rheology of basalt in its melting range. 'He applied the hypothesis of shear melting to magma generation and suggested that the thermal instabilities might give rise to a sort of viscous failure for deep-focus earthquakes. Shaw [1970] suggested that partly molten regions of the upper mantle (for example, beneath the mid-oceanic ridges) could serve as a foci for the dissipation of tidal energy in the earth and that a tidal-magmatic mechanism could act as a trigger to convective circulation in the mantle.

For the next few years major experimental efforts can be anticipated in determination of the melting relationships of synthetic model systems and whole-rock compositions to high pressures. The melting interval will be studied under dry conditions, with excess water, with mixed volatiles and oxygen fugacity controlled, and especially under water-deficient conditions. More will be learned about distribution coefficients of elements among coexisting minerals and liquids in high-pressure experiments. The effect of partial melting on the physical properties of rocks at high pressures should also receive much more attention.

\section{REFERENCES}

Akimoto, S., and E. Komada, Effect of pressure on the melting of olivine and spinel polymorph of $\mathrm{Fe}_{2} \mathrm{SiO}_{4}, J$. Geophys. Res., $72,679-686,1967$.
Anderson, D. L., Petrology of the mantle, Mineral. Soc. Amer. Spec. Pap. 3, edited by B. A. Morgan, 1970.

Anderson, D. L., and C. Sammis, The low velocity zone, Geofis. Int., 9, 3-19, 1969.

Archambeau, C. B., E. A. Flinn, and D. G. Lambert, Fine structure of the upper mantle, J. Geophys. Res., 74, $5825-5865,1969$.

Bell, P. M., and B. T. C. Davis, Melting relations in the system jadeite-diopside at 30 and 40 kilobars, Amer. J. Sci., 267-A, $17-32,1969$

Bell, P. M., and E. H. Roseboom, Melting relationships of jadeite and albite to 45 kilobars with comments on melting diagrams of binary systems at high pressures, Mineral. Soc. Amer. Spec. Pap. 2, edited by J. J. Papike, 1969.

Birch, F., Density and composition of the upper mantle: First approximation as an olivine layer, in The Earth's Crust and Upper Mantle, Geophys. Monogr. 13, edited by P. J. Hart, pp. 18-36, AGU, Washington, D. C., 1969.

Boettcher, A. L., The system $\mathrm{CaO}-\mathrm{Al}_{2} \mathrm{O}_{3}-\mathrm{SiO}_{2}-\mathrm{H}_{2} \mathrm{O}$ at high pressures and temperatures, J. Petrol., 11, 337--379, 1970.

Boettcher, A. L., and P. J. Wyllie, Hydrothermal melting curves in silicate-water systems at pressures greater than 10 kilobars, Nature, 216, 572-573, 1967.

Boettcher, A. L., and P. J. Wyllie, Melting of granite with excess water to 30 kilobars pressure, J. Geol., 76, 235-244, 1968.

Boettcher, A. L., and P. J. Wyllie, Phase relationships in the sy stem $\mathrm{NaAlSiO}_{4}-\mathrm{SiO}_{2}-\mathrm{H}_{2} \mathrm{O}$ to 35 kilobars pressure, Amer. $J$. Sci., 267, 875-909, 1969a.

Boettcher, A. L., and P. J. Wyllie, The system $\mathrm{CaO}-\mathrm{SiO}_{2}-$ $\mathrm{CO}_{2}-\mathrm{H}_{2} \mathrm{O}, 3$, Second critical end-point on the melting curve, Geochim. Cosmochim Acta, 33, 611-632, $1969 b$.

Brett, P. R., and P. M. Bell, Melting relations in the Fe-rich portion of the system $\mathrm{Fe}-\mathrm{FeS}$ at $30 \mathrm{~kb}$ pressure, Carnegie Inst. Washington Yearb., 67, 198-199, 1969.

Burnham, C. W., Hydrothermal fluids at the magmatic stage, in Geochemistry of Hydrothermal Ore Deposits, edited by H. L. Barnes, pp. 34-76, Holt, Rinehart, and Winston, New York, 1967.

Cohen, L. H., K. Ito, and G. C. Kennedy, Melting and phase relations in an anhydrous basalt to $\mathbf{4 0}$ kilobars, Amer. J. Sci., $265,475-518,1967$.

Eggler, D. H., Water-saturated and undersaturated melting relations in two natural andesites (abstract), Abstr. Programs Geol. Soc. Amer., part 2, 544, 1970.

Emslie, R. F., and D. H. Lindsley, Experiments bearing on the origin of anorthositic intrusions, Carnegie Inst. Washington Yearb., 67, 108-112, 1969.

Gibbon, D. L., and P. J. Wyllie, Experimental studies of igneous rock series: The Farrington complex, North Carolina, and the Star Mountain rhyolite, Texas, J. Geol., 77, 221-239, 1969. Gilbert, M. C., High pressure stability of acmite, Amer. J. Sci., $267-A, 145-159,1969$.

Hill, R. E. T., and A. L. Boettcher, Water in the earth's mantle: Melting curves of basalt-water and basalt-water-carbon dioxide, Science, 167, 980-981, 1970.

Holloway, J. R., and C. W. Burnham, Phase relations and compositions in basalt $-\mathrm{H}_{2} \mathrm{O}-\mathrm{CO}_{2}$ under the Ni-NiO buffer at high temperatures and pressures (abstract), Abstr. Programs Geol. Soc. Amer., part 7, 104-105, 1969.

Hsu, L. C., Melting of fayalite up to 40 kilobars, J. Geophys. Res., 72, 4235-4244, 1967.

Ito, K., and G. C. Kennedy, Melting and phase relations in a natural peridotite to 40 kilobars, Amer. J. Sci., 265, 519-538, 1967.

Ito, K., and G. C. Kennedy, Melting and phase relations in the plane tholeiite-lherzolite-nepheline basanite to 40 kilobars with geological implications, Contrib. Mineral. Petrol., 19, $177-211,1968$.

Kennedy, G. C., and S. N. Vaidya, The effect of pressure on the melting temperature of solids, J. Geophys. Res., 75, 1019-1022, 1970.

Koster van Groos, A. F., and P. J. Wyllie, Liquid immiscibility in the join $\mathrm{NaAlSi}_{3} \mathrm{O}_{8}-\mathrm{Na}_{2} \mathrm{CO}_{3}-\mathrm{H}_{2} \mathrm{O}$ and its bearing on the genesis of carbonatites, Amer. J. Sci., 266, 932-967, 1968a. 
Koster van Groos, A. F., and P. J. Wyllie, Melting relationships in the system $\mathrm{NaAlSi}{ }_{3} \mathrm{O}_{8}-\mathrm{NaF}-\mathrm{H}_{2} \mathrm{O}$ to 4 kilobars pressure, $J$. Geol., 76, 50-70, $1968 \mathrm{~b}$.

Koster van Groos, A. F., and P. J. Wyllie, Melting relationships in the system $\mathrm{NaAlSi}_{3} \mathrm{O}_{8}-\mathrm{NaCl}-\mathrm{H}_{2} \mathrm{O}$ at 1 kilobar pressure, $J$. Geol., 77, 581-605, 1969 .

Kushiro, I., Compositions of magmas formed by partial zone melting of the earth's upper mantle, J. Geophys. Res., 73, $619-634,1968$.

Kushiro, I., The system forsterite-diopside-silica with and without water at high pressures, Amer. J. Sci., 267-A, 269-294, 1969.

Kushiro, I., Systems bearing on melting of the upper mantle under hydrous conditions, Carnegie Inst. Washington Yearb., $68,240-245,1970 a$.

Kushiro, I., Stability of amphibole and phlogopite in the upper mantle, Carnegie Inst. Washington Yearb., 68, 245-247, $1970 b$.

Kushiro, I., H. S. Yoder, and M. Nishikawa, Effect of water on the melting of enstatite, Bull. Geol. Soc. Amer., 79, $1685-1692,1968$.

Lambert, I. B., and P. J. Wyllie, Stability of hornblende and a model for the low velocity zone, Nature, 219, 1240-1241, 1968.

Lambert, I. B., and P. J. Wyllie, Melting in the deep crust and upper mantle and the nature of the low velocity layer, Phys. Earth Planet. Interiors, 3, 316-322, $1970 a$.

Lambert, I. B., and P. J. Wyllie, Low-velocity zone of the earth's mantle: Incipient melting caused by water, Science, 169 $764-766,1970 b$.

Lambert, I. B., J, K. Robertson, and P. J. Wyllie, Melting reactions in the system $\mathrm{KAlSi}_{3} \mathrm{O}_{8}-\mathrm{SiO}_{2}-\mathrm{H}_{2} \mathrm{O}$ to 18.5 kilobars, Amer. J. Sci., 267, 609-626, 1969.

Lindsley, D. H., Melting relations of $\mathrm{KAlSi}_{3} \mathrm{O}_{8}$ : Effect of pressure up to 40 kbars, Amer. Mineral., 51, 1793-1799, 1966.

Lindsley, D. H., P-T projection for part of the system kalsilitesilica, Carnegie Instit. Washington Yearb., 65, 244-247, 1967.

Luedemann, H. D., and G. C. Kennedy, Melting curves of lithium, sodium, potassium, and rubidium to 80 kilobars, $J$ Geophys. Res., 73, 2795-2805, 1968.

Luth, W. C., The systems $\mathrm{NaAlSi}_{3} \mathrm{O}_{8}-\mathrm{SiO}_{2}$ and $\mathrm{KAlSi}_{3} \mathrm{O}_{8}-\mathrm{SiO}_{2}$ to $20 \mathrm{~kb}$ and the relationship between $\mathrm{H}_{2} \mathrm{O}$ content, $P_{\mathrm{H}_{2}} \mathrm{O}$ and $\boldsymbol{P}_{\text {total }}$ in granitic magmas, Amer. J. Sci., 267-A, 325-341, 1969.

McDowell, S. C., and P. J. Wyllie, Experimental studies of igneous rock series: Alkaline complex at Kungnat, Greenland, Geol. Soc. Amer. Spec. Pap., 115, 144, 1967.

MacGregor, I. D., The system $\mathrm{MgO}-\mathrm{SiO}_{2}-\mathrm{TiO}_{2}$ and its bearning on the distribution of $\mathrm{TiO}_{2}$ in basalts, Amer. J. Sci., 267-A, $342-363,1969$

Merrill, R. B., J. K. Robertson, and P. J. Wyllie, Melting reactions in the system $\mathrm{NaAlSi}_{3} \mathrm{O}_{8}-\mathrm{KAlSi}_{3} \mathrm{O}_{8}-\mathrm{SiO}_{2}-\mathrm{H}_{2} \mathrm{O}$ to 20 kilobars compared with results for other feldspar-quartz- $\mathrm{H}_{2} \mathrm{O}$ and rock- $\mathrm{H}_{2} \mathrm{O}$ systems, $J$. Geol., 78, 558-569, 1970.

Millhollen, G. L., Melting of Blue Mountain nephaline syenite with $\mathrm{H}_{2} \mathrm{O}$ and $\mathrm{H}_{2} \mathrm{O}+\mathrm{CO}_{2}$ : The condition $P_{e \mathrm{H}_{2} \mathrm{O}}<P_{\text {total }}$ (abstract), Abstr. Programs Geol. Soc. Amer., part 2, 624625,1970

Millhollen, G. L., and P. J. Wyllie, Relationship of brown hornblende mylonite to spinel peridotite mylonite at St. Paul's rocks: Experimental melting study at mantle pressures (abstract), Abstr. Programs Geol. Soc. Amer., part 2, 625, 1970.

Modreski, P. J., and A. L. Boettcher, The stability of phlogopite in the earth's mantle (abstract), Abstr. Programs Geol. Soc.
Amer, part 2,626-627, 1970

Morse, S. A., Alkali feldspars with water at $5 \mathrm{~kb}$ pressure, J. Petrol., 11, 221-251, 1970.

O'Hara, M. J., and H. S. Yoder, Formation and fractionation of basic magmas at high pressures, Scot. J. Geol., 3, 67-117, 1967.

Piwinskii, A. J., Experimental studies of igneous rock series, central Sierra Nevada batholith, California, J. Geol., 76 , $548-570,1968$

Piwinskii, A. J., and P. J. Wyllie, Experimental studies of igneous rock series: A zoned pluton in the Wallowa batholith, Oregon, J. Geol., 76, 205-234, 1968

Piwinskii, A. J., and P. J. Wyllie, Experimental studies of igneous rock series: Felsic body suite from the Needle Point pluton, Wallowa batholith, Oregon, J. Geol., 78, 52-76, 1970.

Presnall, D. C., The geometrical analysis of partial fusion, Amer. J. Sci., 267, 1178-1194, 1969.

Robertson, J. K., Experimental studies on rocks from the Deboullie stock, northern Maine, including melting relations in the water-deficient environment (abstract), Abstr. Programs Geol. Soc. Amer., part 2, 664, 1970.

Sharp, W. E., Melting curves of sphalerite, galena, and pyrrhotite and the decomposition curve of pyrite between 30 and 65 kilobars, J. Geophys. Res., 74, 1645-1652, 1969.

Shaw, H. R., Rheology of basalt in the melting range, J. Petrol., 10, 510-535, 1969

Shaw, H. R., Earth tides, global heat flow, and tectonics, Science, 168, 1084-1087, 1970.

Shaw, H. R., D. L. Peck, T. L. Wright, and R. Okamura, The viscosity of basaltic magma: An analysis of field measurements in Makaopuhi lava lake, Hawaii, Amer. J. Sci., 266, 225-264, 1968.

Spetzler, H., and D. L. Anderson, The effect of temperature and partial melting on velocity and attenuation in a simple binary system, J. Geophys. Res., 73, 6051-6060, 1968.

Stewart, D. B., Four-phase curve in the system $\mathrm{CaAl}_{2} \mathrm{Si}_{2} \mathrm{O}_{8}-\mathrm{SiO}_{2}-\mathrm{H}_{2} \mathrm{O}$ between 1 and 10 kilobars, Schweiz. Mineral. Petrogr. Mitt., 47, 35-59, 1967.

Tuthill, R. L., Effect of varying $f_{\mathrm{O}_{2}}$ on the hydrothermal melting and phase relations of basalt (abstract), EOS, Trans. AGU, 50, 355,1969

Walsh, J. B., Attenuation in partially melted material, $J$. Geophys. Res., 73, 2209-2216, 1968

Walsh, J. B., New analysis of attenuation in partially melted rock, J. Geophys. Res., 74, 4333-4337, 1969.

Whitney, J. A., and W.C. Luth, Water undersaturated melting of natural granites at $2 \mathrm{~kb}$ (abstract), EOS, Trans. $A G U, 51,438$, 1970.

Williams, D. W., and G. C. Kennedy, Melting curve of diopside to 50 kilobars, J. Geophys. Res., 74, 4359-4366, 1969

Wyllie, P. J., Ultramafic rocks and the upper mantle, Mineral. Soc. Amer. Spec. Pap. 3, edited by B. A. Morgan, 319 pp., 1970.

Wyllie, P. J, , and A. L. Boet tcher, Liquidus phase relationships in the system $\mathrm{CaO}-\mathrm{CO}_{2}-\mathrm{H}_{2} \mathrm{O}$ to 40 kilobars pressure with petrological applications, Amer. J. Sci., 267A, 489-508, 1969.

Yoder, H. S., Calkalkalic andesites: Experimental data bearing on the origin of their assumed characteristics, Oreg. Dep. Geol. Miner. Ind. Bull. 65 , edited by A. B. McBirney, Portland, 1969.

Yoder, H. S., Phlogopite- $\mathrm{H}_{3} \mathrm{O}-\mathrm{CO}_{2}$ : An example of the multicomponent gas problem, Carnegie Inst. Washington Yearb. 68, $236-240,1970$.

Yoder, H. S., and I. Kushiro, Melting of a hydrous phase: Phlogopite, Amer. J. Sci., 267A, 558-582, 1969. 